\title{
Lighting design and modern trends in the organization of museum exhibitions
}

\section{Dilnoza SAIPOVA ${ }^{1}$}

Kamoliddin Behzod national institute of fine arts and design

\section{ARTICLE INFO}

Article history:

Received October 2021

Received in revised form

15 October 2021

Accepted 20 November 2021

Available online

15 December 2021

\section{Keywords:}

musion,

exterior,

interior,

design,

composition.

\section{ABSTRACT}

This article analyzes an overview of lighting design projects and organizations of expositions in museums of Uzbekistan. Which is aimed at combining modern and national ideas, searching for creative solutions in interior and exterior design. These projects will help people of all ages, especially young people, to create and develop their creative abilities. To increase spiritual and cultural values. This will give the most complete picture of the history and culture of Uzbekistan to both compatriots and foreign tourists. Preservation of historical and cultural heritage means national identity, national culture in the context of globalization. One of the important factors in the development of these projects in the cultural and tourism field is the study of the activities of international and national organizations. Who are engaged in projects of revival, preservation of cultural and national traditions.

2181-1415/C 2021 in Science LLC.

DOI: https://doi.org/10.47689/2181-1415-vol2-iss11/S-pp7-15

This is an open access article under the Attribution 4.0 International (CC BY 4.0) license (https://creativecommons.org/licenses/by/4.0/deed.ru)

\section{Музейларни ташкил қилишда ёруғлик дизайни ва замонавий тенденциялар}

\author{
Калит сўзлар: \\ мусион, \\ фое, \\ экстерьер, \\ интерьер, \\ дизайн, \\ композиция.
}

\begin{abstract}
АННОТАЦИЯ
Ушбу мақолада Ўзбекистон музейлари лойихасида замонавий ва миллий ғояларни уйғунлаштириш, барча ёшдаги инсонларни, жумладан, ёшларнинг ижод қилиши, қобилиятларини ривожлантириши, маънавий-маданий савиясини ошириш ва хар томонлама ижодкорлик махоратининг ўсишига хизмат қиладиган интерьер ва экстерьер дизайнининг бадиий ечимларини топишга қаратилган илмий изланишни амалга оширишда музейлар
\end{abstract}

\footnotetext{
${ }^{1}$ Senior lecturer, “Design” department, Kamoliddin Behzod national institute of fine arts and design. Tashkent, Uzbekistan.
} 
ўрни беқиёс эканлиги хақида тушунчалар беради. Глобаллашув жараёнлари хаётимизнинг барча сохаларига кириб бораётган шароитда тарихий-маданий меросни асраш миллий ўзликни, миллий маданиятни сақлаб қолиш демакдир. Мазкур соха ривожида таянч бўлган халқаро ва миллий ташкилотлар фаолиятини тадқиқ этиш, ўрганиш мухим омиллардан саналади.

\section{Световой дизайн и современные тенденции в организации экспозиции музеев}

\author{
Ключевые слова: \\ musion, \\ фойе, \\ экстерьер, \\ интерьер, \\ дизайн, \\ композиция.
}

\begin{abstract}
АННОТАЦИЯ
В данной статье анализируется обзор проектов светового оформления и организаций экспозиций в музеях Узбекистана. Который направлен на объединение современных и национальных идей, поиск творческих решений в дизайне интерьера и экстерьера. Данные проекты помогут людям всех возрастов, особенно, молодежи, творить, развивать свои творческие способности. Приумножить духовные и культурные ценности. Это даст наиболее полное представление об истории и культуре Узбекистана, как соотечественникам, так и зарубежным туристам. Сохранение историко-культурного наследия, означает национальную самобытность, национальной культуры в условиях глобализации. Одним из важных факторов развития данных проектов в культурной и туристической области, является изучение деятельности международных и национальных организаций. Которые занимаются проектами возрождения, сохранения культурных и национальных традиций.
\end{abstract}

In order to organize the interior design of the museum at the level of modern requirements, a very important issue remains the training of highly qualified art historians and museologists, designers. The production of trainings and advanced training programs in accordance with modern requirements for high-tech production, the integration of theoretical training with practice. After the Republic of Uzbekistan gained independence, the state's attention to the cultural heritage and national values, the history of our people, spirituality has increased. This museology is also reflected in published documents. A deep understanding of the Inter Museum approach allows you to get acquainted with modern design.

The most important architectural memorials are monuments. Here the generally accepted concept of the museum as a place for storing original exhibits was confirmed: firstly, the monument is created not by museum means, but by architectural and artistic means. The natural environment, the environment in which the complex is preserved or created, plays an important role in the architectural and spatial formation of the ensemble. When decorating the interior of the museum, future designers will focus on the treasury of the museum, mainly on materials, pictorial objects, as well as works of art. When decorating the interior, the museum's treasury of future designers will publish materials, artifacts, products, works of art, as well as written sources on window dressing. The 
modern museum is a complex, multifunctional organism. It is therefore organized according to the three main parts of the overall program.

Museum staff - functional program, thematic and scientific content of the exposition;

1) architects - spatial planning and functional technological solutions;

2) artists, designers - the figurative image of the exhibition.

3) The design process usually consists of the following sequences.

4) The first stage: the author's team, the features of the museum itself, the thematic structure of the exposition, the process of the future design of the museum is usually an expression from the following series.

The first stage: the team of authors, the features of the museum, the thematic structure of the exposition, the scientific concept of the development of the museum for the near future and the future, the approximate composition and building area, urban planning, architectural and artistic options.

On September 1, the President of the Republic of Uzbekistan Shavkat Mirziyoyev visited the Khazrati Imam (Hastimom) complex in Tashkent to get acquainted with the project of Islamic civilization, organized on the basis of the decree. The President proposed to rename the center to the Center for Islamic Civilization.

According to the project, an academy, a library, an archive and a manuscript fund were created at the center, as well as manuscripts of great thinkers who grew up in Uzbekistan today. According to the project, the center will have an academy, a library, an archive and a manuscript fund, which will store ancient manuscripts and lithographs of scientific and religious schools founded by great thinkers who grew up in modern Uzbekistan. Historical documents, archaeological finds, relics, modern research in this area, enrichment of video and photo documents, construction of a conference hall for 300 seats. "We have always been proud of our ancestors", said the head of state.

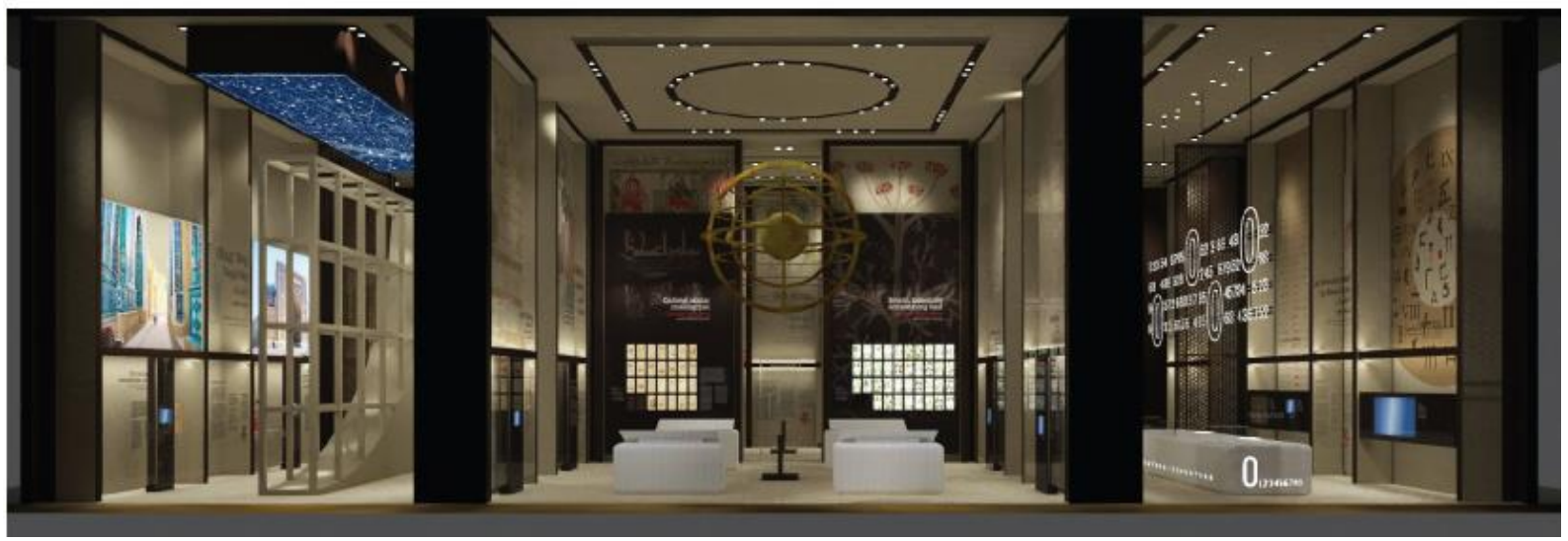

Fig 1. Wall paintings of the Al-Khorezmi department of the museum

"This center will be our face in the spread of Islam. Therefore, it is important to pay attention to its appearance, as well as the building materials used here. It is necessary to abandon the usual, familiar projects and find a new form and design", said the President. On the basis of this instruction, scientists, leading specialists, artists and designers began to work, headed by the director of the Center for Islamic Civilization Shoazim Minavarov. The French company Wilmotte \& Associes Architectes has also begun preparing project 
proposals. The exterior of the building of the Center for Islamic Civilization was designed in accordance with national traditions and includes all elements of modern interpretation, such as entrances, patterns, carvings, mukarnas. scientific study of the achievements of the country's history in the new period of its rise, its dissemination among the general public; propaganda of samples of material and cultural heritage, ancient and rich traditions associated with Islam.... Judging by the photos below, the designers enrich the interiors of the museum even more. Along with the creative search, we see that at the same time scientific research is being solved. Illustrating the content of the "Third Renaissance", designers turn to ancient sources. The general principles of museum design discussed above are organized in historical buildings, taking into account their preservation and architectures.

IBN-SINA | ИБН СИНО
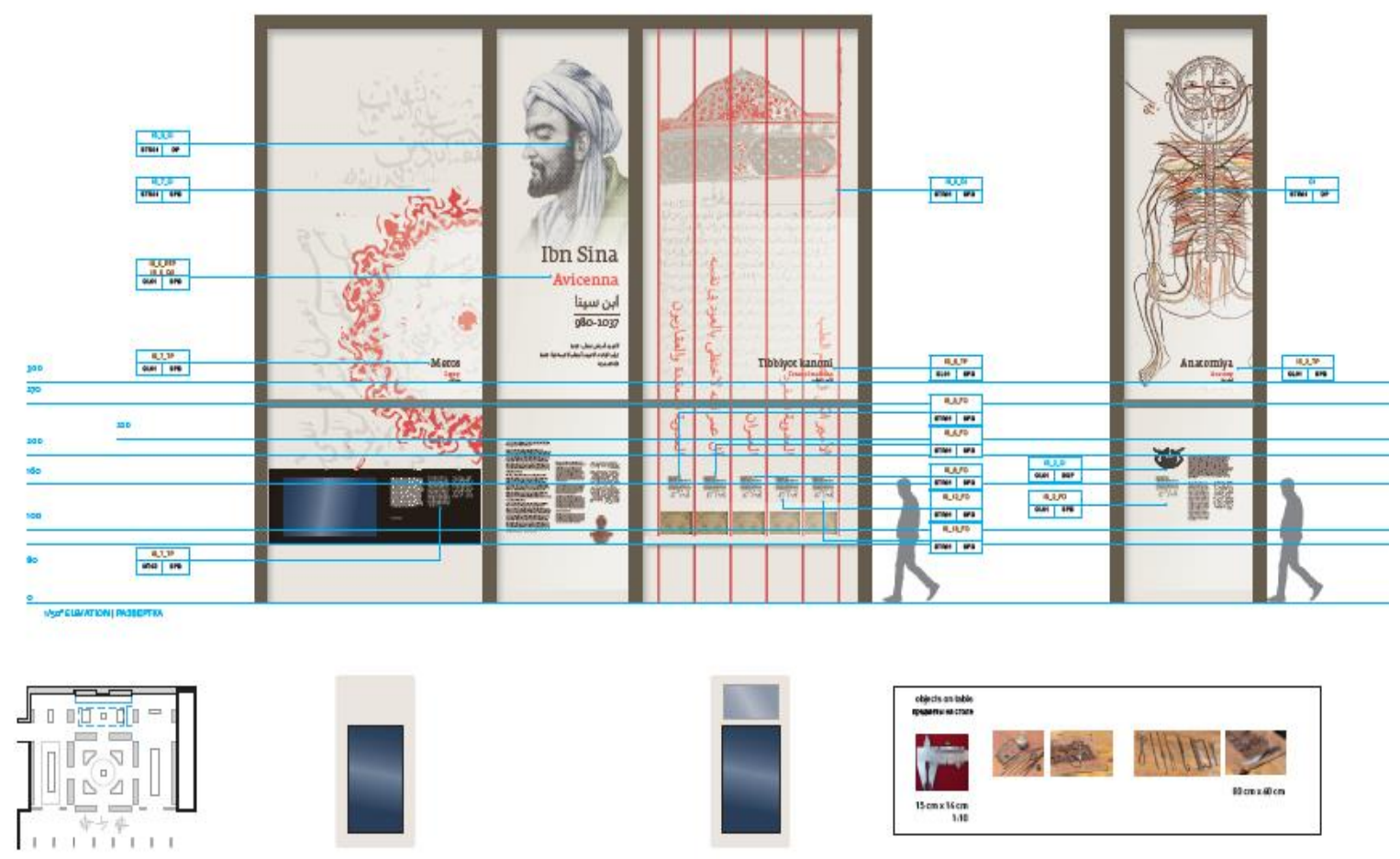

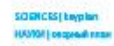
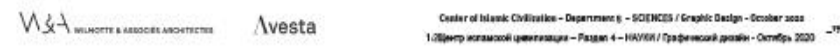

Fig 2. Promotion of the idea of "Third Revival - New Uzbekistan";

Scientific study of the achievements of the country's history in the new period of its rise, its dissemination among the general public; propaganda of samples of material and cultural heritage, ancient and rich traditions associated with Islam.... Judging by the photos below, the designers enrich the interiors of the museum even more. Along with the creative search, we see that at the same time scientific research is being solved. Illustrating the content of the "Third Renaissance", designers turn to ancient sources. The general principles of museum design discussed above are organized in historical buildings, taking into account their preservation and architectural features. 

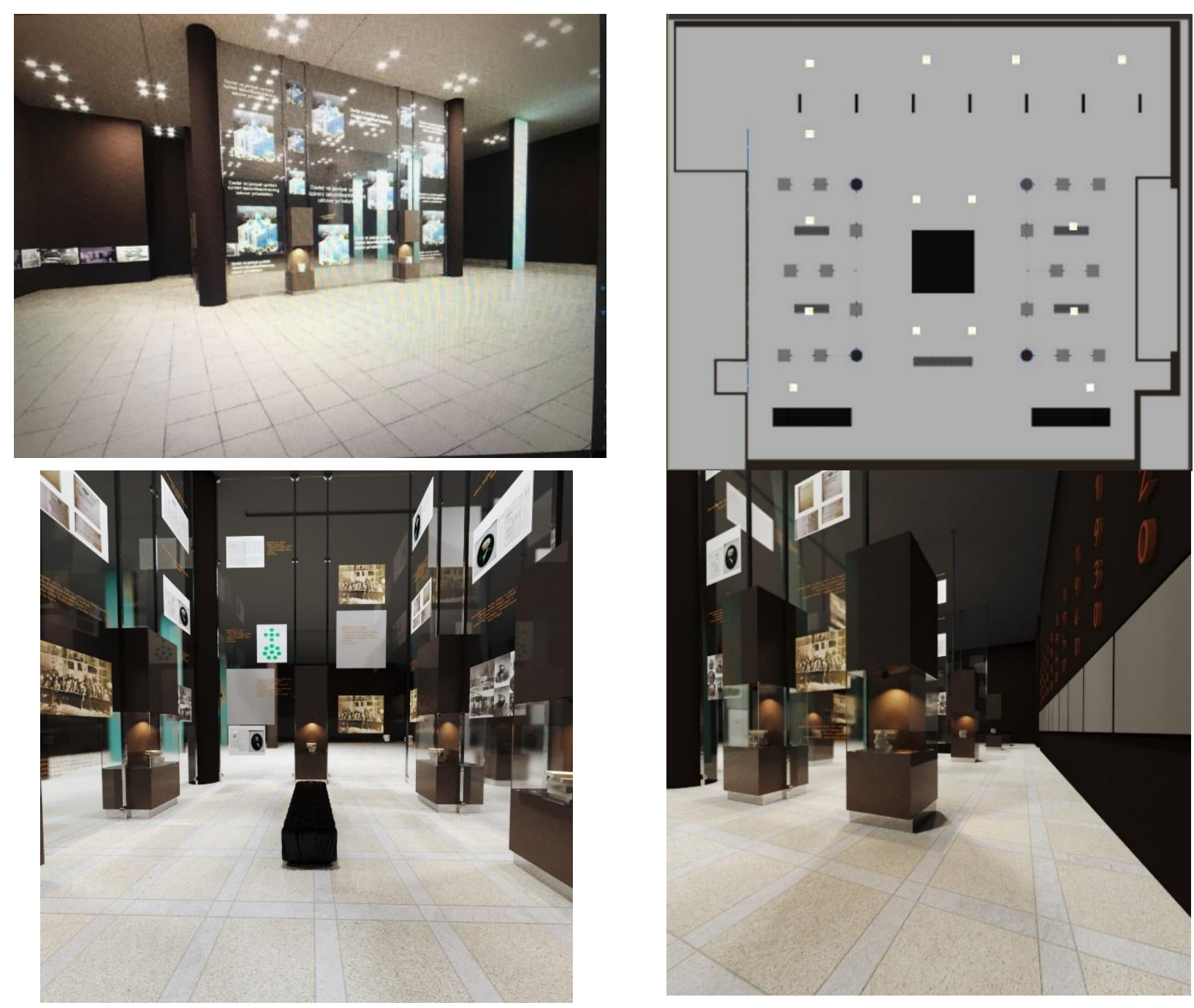

Fig 3. The first proposal of Uzbek designers 0. Kasimov and D. Saipova.

The project was carried out without deviating from the general concept, while the color balance in the project of French designers was preserved. The reason is to keep the overall color scheme. In the design part of the project, all elements are located in the center of the circle. The center has three model projects, which will include three renaissances in Uzbekistan. The ceiling of the museum reflects the arrangement of the stars around the center.

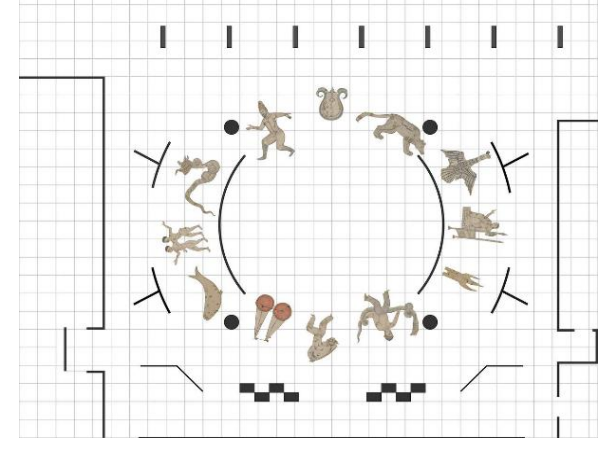

Fig 4. History and view on the ceiling of the Third Renaissance section of the museum.Design: 0. Kasimov and D. Saipova. 
In this interior of the museum, great attention is paid to the chronological arrangement of all exhibits, photographs and information. Doctor of Historical Sciences, Professor, Head of the Department of History and Anthropology of the East, Tashkent State University of Oriental Studies Shodmonova Sanobar Bazarbaevna, Candidate of Historical Sciences, Tashkent State University of Oriental Studies, Associate Professor of the Department of History and Anthropology of the East Shamsieva Iroda Makhmudovna, G. Major scientists such as Ilkhomjanov Lutfulla Sultanovich, senior researcher at the HouseMuseum of Gafur Gulom work here. Judging by the photos below, the designers enrich the interiors of the museum even more. Along with the creative search, we see that at the same time scientific research is being solved. Illustrating the content of the "Third Renaissance", designers turn to ancient sources. The general principles of museum design discussed above are organized in historical buildings, taking into account their preservation and architectural features. There are museums such as nature reserves, ethnography and open-air museums.
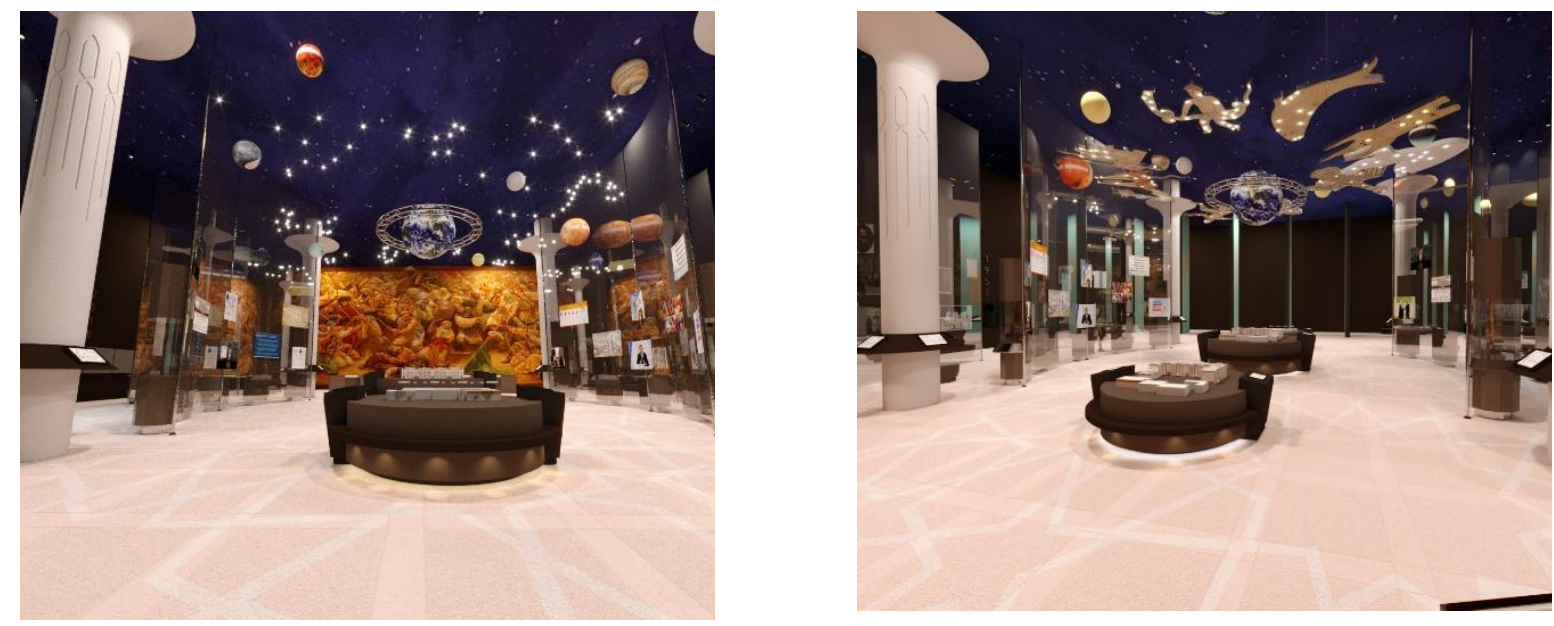

Fig 5. It should be noted that the color scheme of the museum's interior is a combination of oriental style.

Artificial lighting plays an important role in illuminating the interior of a museum. Light helps to clearly see the exhibits, distinguish them from other exhibits and not mislead, avoid unnecessary information. The calculation of lighting in museum halls has become too theoretical; The main thing is the quality of light. In this regard, the experience of American specialists is very indicative. In recent years, there has been less natural light and more artificial light. Especially if the interior windows of the museum face north. Light sources are divided into 2 types: natural and artificial.

1. Natural light (sun, stars),

2. Divided into artificial light (candles, bonfires, electric lamps).

Fluorescent light-emitting substances are called fluorescent substances or phosphors. Luminescent phenomena differ in the mechanism of atomic excitation. The reason for fluorescent lighting is the presence of various metal salts. Some of them glow for hours after exposure (phosphorescence), for others a second is enough. (fluorescent short-term glow Atoms that move in 10-8 seconds). Light excites the atoms of the material (increases ix internal energy), then releases energy in the form of light. Lighting design (English Lighting - design, development, construction, calculation of lighting) is a design 
direction based on three main aspects of lighting. Aesthetic perception is important in the design and implementation of lighting in places of long-term residence of people: recreation areas, parks, squares, shops, public places and architectural forms. Ergonomics is the characteristic of light, the ability of light to affect performance, comfort, and visual experience. Energy saving - it is important to understand that there is no excess without a reason; is there space lighting, without a special semantic load; whether the illumination values exceed those required by regulatory documents or fulfill aesthetic and functional functions. Each of these aspects should be considered in the work of a lighting designer. From an aesthetic point of view, a lighting designer must understand how to enhance the attractiveness of the illuminated space, how the object interacts with the surrounding background (cracked or detached from it) and how the light should evoke emotion. Please note that the object is visible not only at night, but also during the day; take into account the requirements of day and night safety (excessive glare in the field of view of the observer, color and light pollution, etc.).

Light design, like architecture, is not an art or science, but the industry from which they originate. A professional lighting designer requires not only a creative idea (from an artistic point of view), but also an understanding of the physical properties of light and how lamps and light sources work (from a scientific point of view).

\section{REFERENCES:}

1. Mirziyoyev Sh. Together with our brave and noble people, we will build our great future. NMIU “Uzbekistan”, 2017. - P. 344.

2. Kuryazov D.T. "Fundamentals of Museum Business.

3. Measures to implement the Strategy of Action in five priority areas of development of the Republic of Uzbekistan for 2017-2021 (Collected Legislation of the Republic of Uzbekistan, 2017, No. 7, Art. 88).

4. Fundamentals of museum work D.T. Kuryazov. October 2018

5. Creation of the State Museum of the History of the Temurids and the Memorial Museum of the Victims of Repression and their educational value. Azamzhanov A., Orifjonova G. Volume IV Scientific-practical conference through the eyes of art and youth. Tashkent $2016.26 \mathrm{p}$.

6. Saipova D.S. et al. Problems and Solutions in Studying the Modern Design of Museum Interiors // JournalNX. - PP. 241-245.

7. Sh S.D. Modern museums cultural heritage for future youth // ASIAN JOURNAL OF MULTIDIMENSIONAL RESEARCH. - 2021. - T. 10. - №. 4. - PP. 733-737.

8. Mukaddas I. et al. Creating an Architectural Environment for Unemployed People with Disabilities in Uzbekistan // Design Engineering. - 2021. - PP. 12165-12172.

9. Makhmudova M., Makhmudova M. THE ROLE OF RESTORATION AND SCIENTISTS IN THE PRESERVATION OF ARCHITECTURAL MONUMENTS OF THE TEMURID PERIOD // SOCIETY. INTEGRATION. EDUCATION. Proceedings of the International Scientific Conference. - 2021. - T. 4. - PP. 575-587.

10. Kizi Sultanova M.F. The Role of Tour Bases In The Development Of Tourism In Uzbekistan // INTERNATIONAL SCIENTIFIC AND CURRENT RESEARCH CONFERENCES. 2021. - PP. 1-5.

11. Malika Makhmudova. RESTORATION OF MONUMENTS OF UZBEKISTAN ARCHITECTURE. Look to the past. 2021, vol. 4, Issue 6. - PP. 53-59. 
12. Kamalova F.K.Q. ARXITEKTURA VA INTERYER MAKETINI YASASHDA XOMASHYO VA MATERIALLARNING ORNI // Scientific progress. - 2021. - T. 1. - №. 5.

13. Akhunova N.K.K. Possibilities of using virtual reality technologies in education // Asian Journal of Multidimensional Research (AJMR). - 2021. - T. 10. - №. 3. - PP. 549-555.

14. Badirovna I.M. The specificities of creating and developing modern campuses. -2021 .

15. Mannopova N., Mannapov A. Influence of "Thematic Parks" to the development of tourism in Uzbekistan // ASIAN JOURNAL OF MULTIDIMENSIONAL RESEARCH. - 2021. - T. 10. - №. 4. - PP. 696-704.

16. Mannopova N.R., Kamolkhodjaeva M.B. Features of designing interiors of restaurant establishments // ASIAN JOURNAL OF MULTIDIMENSIONAL RESEARCH. 2021. - T. 10. - №. 4. - PP. 711-715.

17. Marufovich M.Y. Some Features Of The Connection Between The Interior And The Environment // International Journal of Progressive Sciences and Technologies. 2021. - T. 26. - №. 1. - PP. 97-101.

18. Makhmudova M.T. Features of a country house in hot countries // ACADEMICIA: An International Multidisciplinary Research Journal. - 2021. - T. 11. - №. 3. - C. 2167-2173.

19. Makhmudova M.T. A masterpiece of the avant-garde era in Russia-melnikov's house // ASIAN JOURNAL OF MULTIDIMENSIONAL RESEARCH. - 2021. - T. 10. - №. 4. PP. 642-647.

20. Takhirovna M.M. ART NOUVEAU MASTERPIECE-RYABUSHINSKY MANSION //ResearchJet Journal of Analysis and Inventions. - 2021. - T. 2. - №. 05. - C. 133-139.

21. Tursunova S.F. Light in the modern world // ASIAN JOURNAL OF MULTIDIMENSIONAL RESEARCH. - 2021. - T. 10. - №. 4. - PP. 750-756.

22. Roziqberdiev M.I. The time has come to move from stereotypes to creativity: In the example of mosques // Asian Journal of Multidimensional Research (AJMR). - 2021. T. 10. - №. 3. - PP. 564-571.

23. Latifovich T.A. Large-span structures and architectural form // ACADEMICIA: AN INTERNATIONAL MULTIDISCIPLINARY RESEARCH JOURNAL. - 2021. - T. 11. - №. 1. - PP. 397-401.

24. Tursunova ShF. "HISTORY OF ADVERTISING IN UZBEKISTAN". International Engineering Journal for Research \& Development 5.9 (2020): 10-10.

25. Sultanova, Muhayyo. "Use of Cultural Plants in Desert Cities in Creating the Landscape of Recreation Zones in Uzbekistan". International Journal on Orange Technologies, vol. 2, no. 10, 20 Oct. 2020. - PP. 102-104. DOI: 10.31149 / ijot.v2i10.738.

26. Razikberdiev M.I. (2020). Southern mesopotamia in the first half of the 3rd millennium bc. Asian Journal of Multidimensional Research (AJMR), 9(5), 211-216.

27. Mannapova N.R. et al. Organization and Basic Requirements For Restaurant Design Interior // International Journal of Innovations in Engineering Research and Technology. - 2020. - T. 7. - №. 05. - PP. 5-12.

28. Mukaddas Isakova. (2020). Influence Of Colors On Children's Mentality In Children's Institutions, Research And Analysis Of Psychologists And Designers. International Journal of Scientific \& Technology Research, 9(2), 5549-5551.

29. Nazokatkhon A. INNOVATIVE TECHNOLOGIES TO REDUCE CLIMATIC EFFECTS IN HOT AND DRY CLIMATIC TERRITORIES // Архитектурада инновациялар журнали. - 2020. - T. 1. - №. 1. 
30. Makhmudova M., Makhmudova M. ISLAMIC STYLE IN LANDSCAPE DESIGN ON THE EXAMPLE OF ANCIENT GARDENS OF THE TEMURID PERIOD // SOCIETY. INTEGRATION. EDUCATION. Proceedings of the International Scientific Conference. 2020. - T. 5. - PP. 706-718.

31. Makhmudova M.T., Makhmudova M.M. (2018). Formation of the Restoration School in Uzbekistan and its Role in Preservation of Architectural Heritage. Interational scientific conference "SOCIETY, INTEGRATION, EDUCATION", Latvia.

32. Makhmudova M., Jumaniyazova D., Abdullahodjaev G. The Landscape Design of the Art Nouveau Style // SOCIETY. INTEGRATION. EDUCATION. Proceedings of the International Scientific Conference. -2015. -T. 2. -C. 391-400.

33. Касымов О.С. Мост двух берегов // Поколение будущего: взгляд молодых ученых. - 2016. - С. 34-37.

34. Kasimov O.S. Formation of Landscape Design in Japan // European Journal of Business and Social Sciences. - 2018. - T. 6. - №. 12. - PP. 30-35.

35. Isakova M.B., Olimova F.J. Principles of formation of children's rehabilitation centers in Uzbekistan // ASIAN JOURNAL OF MULTIDIMENSIONAL RESEARCH. - 2021. T. 10. - №. 5. - PP. 620-626.

36. Мансуров Я. Проектирование как стадии творчества // Общество и инновации. - 2021. - Т. 2. - №. 5. - С. 184-188.

37. Султанова M. Inson psixologiyasiga arxitektura dizayni va undagi hajmlarning ta'siri // Общество и инновации. - 2021. - Т. 2. - №. 5. - С. 177-183.

38. Isakova M. IMKONIYATI CHEKLANGAN BOLALAR SAN'AT MAKTABLARIDA BADIIY TA'LIMNI RIVOJLANTIRISH TAMOYILLARI // Камолиддин Бехзод номидаги Миллий рассомлик ва дизайн институти АХБОРОТНОМАСИ илмий-амалий журнали. - 2021. - T. 5. - №. 03. - С. 98-101. 